\title{
A Study of Effect on the Efficiency in Manufacturing Organizations: The Application of RFID Technology
}

\author{
Diljeetkaur G. Makhija ${ }^{1, *}$, Pawan K. Chugan ${ }^{2}$ \\ ${ }^{1}$ Kalol Institute of Management, Kadi Sarva Vishwavidhyalaya, India \\ ${ }^{2}$ Institute of Management, Nirma University, India
}

Copyright $\mathrm{O} 2016$ by authors, all rights reserved. Authors agree that this article remains permanently open access under the terms of the Creative Commons Attribution License 4.0 International License

\begin{abstract}
RFID technology is a real time tracking system, which does not require line of sight. The technology is trending in the organizations, due to various benefits that it can reap. Every organization wants to increase its efficiency, i.e., get more output with same or less input. The implementation of RFID technology can be done by integrating it with the ERP of the organization for various practices or applications. The organizations can decide the practice/application they want to adopt according to their requirement. The efficiency of the process is affected by this application. Manufacturing Organizations have wide applications of RFID technology and henceforth this sector is considered in the study. The paper focuses on various RFID practices in manufacturing organizations and its effect on the improvement in the efficiency of the organizations. It is found that implementing RFID either for Inventory Management, Work in Progress Management, Logistics Management, In-Process Logistics Management or Warehouse Management; it will lead to improvement in efficiency of the organization.
\end{abstract}

Keywords RFID Technology, Operational Efficiency, RFID Application, RFID Practices

\section{Introduction}

With new advancement in the existing technology, information technology has brought revolution in day to day life of human beings. It brought revolution for industries where tracking of the goods was important but a task which was quiet difficult and complicated, where any mistake could result into huge losses. One such technology, which has attracted increasing attention in recent years, which has brought revolution, is radio frequency identification technology (RFID technology). RFID technology has changed the way manufacturing organizations can have automation work for them. But still organizations show resistance towards adopting the technology because of the high cost and uncertain return on investment (ROI) associated with it. Despite of cost being a drawback, implementation of RFID technology can make the organizations more effective and efficient. If the efficiency of the organization is improved by using the RFID practices, then in the long run ROI can be achieved. This can inspire organizations to adopt the technology more easily. The technology is being utilized in organizations with various applications, but does it affect the efficiency of the organization is a question? The study here will focus on this aspect of adoption to RFID technology. The objective of the study is to explore the practices of RFID technology in manufacturing organizations and analyze the impact of RFID technology practices on the efficiency of the manufacturing organizations.

\section{Literature Review}

\subsection{Introduction to RFID Technology}

Radio frequency identification (RFID) technology is a wireless communication technology that enables users to uniquely identify tagged objects or people [1]. RFID technology is one of the automatic identification and data capture (AIDC) technologies. RFID has been an increasingly popular tool for object identification, and track and trace of goods in the supply chain and manufacturing [1].

The three components of RFID technology are [2-4]:

1. RFID Tag,

2. RFID Reader and

3. Middleware.

RFID Tag is a micro chip with an antenna [5]. The micro chip is attached to the item, which is to be tracked. The data (details) about the item is fed in the microchip. There are three types of tags, Active tags, Passive tags and Semi Passive Tags. The tags which have their own batteries for power supply are called active tags, while the ones which do not have any source of power supply of their own are passive 
tags. Passive tags get activated once they come in the range of reader, as they get power from the radio waves. Tags which have their own batteries, but use the power of the readers are called semi passive tags. Active and Semi passive tags are costlier than the passive tags.

RFID reader emits radio waves, which detect the tags within the range. Once they detect a tag, they read the data in the tag and the same to the middleware along with the time and location of the tag [6]. RFID reader can read multiple tags simultaneously.

Middleware is the software application made according to the requirement of the organization which connects the RFID system to the ERP (Enterprise Resource Planning) of the organization. Middleware receives the data from the reader, decodes it and feeds it into the ERP of the organization for further processing.

This makes the functioning of the system on real time basis, and making it suitable for automation operations. RFID technology is being widely used in various industries. It has brought a revolution in the use of library management [2].

\subsection{Importance of RFID in Manufacturing Organisations}

RFID has a wide range of applications in manufacturing industry including inventory management, asset tracking, process tracking and product and process planning [7-13]. The technology and application software interface has the potential to capture large amount of data which helps in improving and controlling the operations and better decision making. There are many drivers/triggers for adopting RFID technology in manufacturing organizations [14].

Manufacturing organizations should be efficient and effective and adoption of RFID technology makes the organization efficient as well as effective $[15,16]$. By implementation of RFID technology raw material, work in process and finished goods can be managed efficiently by eliminating waste and reducing stock out, also it helps in improving production planning and proper utilization of resources [17, 18]. RFID technology when linked to the ERP of an organization will improve the coordination between the supply chain partners [16]. RFID technology can thus have a positive effect on the efficiency of the manufacturing organization and its supply chain partners $[16$, 18-20].

RFID comes with benefits such as enhanced visibility, asset tracking and returnable items, item level tracking, traceable warranties and product recalls, quality control and regulation, ability to withstand harsh environments [21]. Despite of the various benefits provided by RFID, one of the major issues with RFID technology adaptation has been the cost of RFID and uncertain return on investment. The cost of a fully functional RFID system includes entire infrastructure and strategy change.

\subsection{Introduction to the Practices of RFID Technology in Manufacturing Organizations}

Keeping the above mentioned benefits in concern, RFID applications are usually designed closed to the Manufacturing Execution System (MES) which controls the production process. Some of the functions of MES are Operations Scheduling and Production Control, Labor Management, Maintenance Management, Data Collection, Quality Management, Document Control and Inventory Management [22]. RFID technology may support these functions.

With the linkage of RFID and ERP of an organization, both the customers and suppliers can also be linked with the organization, connecting the whole supply chain of the organization on real time basis and making the work easier and accurate.

In the current scenario, in market there are several vendors present who supply RFID tags or Middleware, applications and services to various manufacturing organizations. Every organization has a different requirement and it may or may not link it with its organizational strategy or IT infrastructure. They might link it with IT infrastructure so that they can have all the information automatically generated and stored for better data management [23].

Organizations might link up the RFID application with the organizational strategy, through which they might use it for the whole supply chain planning and might insist their suppliers or customers to use the technology as well. Or they might link up with overall IT strategy of the organization to have real time data for decision making [24- 26].

Apart from it, vendors provide different packages to organizations for implementation of RFID. For example, Inventory Management, Warehouse Management, Work in process Management, Logistics Management, In process logistics Management, Employee Management, and Supply Chain Management. Organizations may take individual or multiple packages as per their requirement. Different vendors might provide different benefits under the same application. Also, the organizations are provided with small practices for the manufacturing purposes.

The study here focuses on five major practices of RFID, namely Inventory Management (IM), Work in Progress Management (WIPM), Logistics Management (LM), Warehouse Management (WM) and In-Process Logistics Management (IPLM).

\section{Research Methodology}

In this study, an attempt has been made to explore the various practices of RFID technology in manufacturing organizations. For this, initially literature review was done to get an insight of various applications/practices of RFID technology in manufacturing organizations. Later exploratory as well as descriptive research methods have been used to analyze the impact of practices of RFID technology on the efficiency of the organizations. 
The Convenience Sampling method was used to select the sample. Initially, about 30 RFID vendors across Gujarat, State of India, were contacted to get the list of 65 manufacturing organizations using RFID technology in their business organizations. All the 65 organizations were contacted for the survey, out of which 52 companies agreed to be surveyed and were included in study. The details of the industry are given in table 1 below:

Table 1. Sample description of respondents

\begin{tabular}{|c|c|}
\hline Industry / Type of Organization & Total Number of Respondents \\
\hline Cement/Ceramic & 13 \\
\hline Textile Industry & 14 \\
\hline Boiler Manufacturers & 12 \\
\hline Pipe \& Tubes Manufacturers & 13 \\
\hline
\end{tabular}

The respondents included the top and middle level managers who were responsible for RFID installation as well as implementation. A structured questionnaire was prepared to conduct the survey. All the statements regarding practices of RFID technology were rated on 1 to 5 on a Likert scale (1 $=$ Least important and $5=$ Most important), also they were asked to rate increase in the efficiency as a benefit achieved through the technology, on the basis of the practices adopted on the Likert scale $(1-$ None and 5 - Very Large). The personal contact method was used to conduct the survey. The questionnaires were sent to respondents in advance before the actual survey that had provided them an opportunity to study the questionnaire in advance and later on during the time of personal discussion their doubts if any, were clarified to get the required information. This has been very useful in increasing the efficiency of respondents' responses.

\section{Data Analysis and Interpretation}

Multiple regression analysis was performed to study the impact of RFID practices on improved efficiency of the organizations. Multiple regression analysis is a multivariate statistical technique used to examine the relationship between a single dependent variable and several independent variables [27]. Here RFID practices were the independent variable and the efficiency of the organization was taken as dependent variable.

For performing the multiple regression analysis, following values of independent variables were considered, Regression Co-efficient, Coefficient of Determination $\left(\mathrm{R}^{2}\right)$ [28], Adjusted $\mathrm{R}^{2}$ [28], ANOVA (F-test) [28], multicollinearity [28]. multicollinearity occurs when any single independent variable is highly correlated with a set of other independent variables [27]. The simplest and most obvious means of identifying collinearity is an examination of the correlation matrix of independent variables. The presence of high correlations (generally .70 or more) is an indication of substantial collinearity [27]. A formal method of detecting the presence of multicollinearity is Variance Inflation
Factors (VIF). The larger values for VIF signal the presence of multicollinearity. The common rule of thumb for a large value of VIF is 10 as described is [29]. If the VIF value is nearer to 10 [29] or more than 10 [30], then it signifies high level of multicollinearity among independent factors.

While performing the regression analysis, all the above statistics were considered.

\subsection{Hypothesis:}

The RFID practices viz. Work in Progress Management (WIPM), Inventory Management (IM), Logistics Management (LM), Warehouse Management (WM) and In-Process Logistics Management (IPLM) create significant improvement on efficiency (IOE) of the organization.

The following are hypothesis have been formed:

1. H(WIPM): There is a significant improvement through usage of RFID in WIPM on IOE.

2. H(IM): There is a significant improvement through usage of RFID in IM on IOE.

3. $\mathbf{H}(\mathbf{L M})$ : There is a significant improvement through usage of RFID in LM on IOE.

4. $\mathbf{H}(\mathbf{W M})$ : There is a significant improvement through usage of RFID in WM on IOE.

5. H(IPLM): There is a significant improvement through usage of RFID in IPLM on IOE.

\subsection{Interpretation:}

The regression co-efficient of the independent variables with their respective direction, values and significance level are given in the table 2 below:

Table 2. Regression coefficients of RFID Practices on Improved Efficiency

\begin{tabular}{|c|c|c|c|c|c|c|c|}
\hline \multirow{2}{*}{ Model } & \multicolumn{2}{|c|}{ Unstd Coeffs } & $\begin{array}{c}\text { Std } \\
\text { Coeff }\end{array}$ & \multirow{2}{*}{$\mathrm{t}$} & Sig. & \multicolumn{2}{|c|}{$\begin{array}{c}\text { Collinearity } \\
\text { Statistics }\end{array}$} \\
\cline { 2 - 4 } \cline { 7 - 8 } & $\mathrm{B}$ & $\begin{array}{c}\text { Std. } \\
\text { Error }\end{array}$ & Beta & & & $\mathrm{B}$ & $\begin{array}{c}\text { Std. } \\
\text { Error }\end{array}$ \\
\hline (Constant) & -.157 & .173 & & -.904 & .371 & & \\
\hline WIPM & .147 & .056 & .139 & 2.624 & .012 & .486 & 2.056 \\
\hline IM & .185 & .044 & .211 & 4.211 & .000 & .543 & 1.842 \\
\hline LM & .231 & .059 & .208 & 3.946 & .000 & .489 & 2.045 \\
\hline WM & .285 & .043 & .332 & 6.645 & .000 & .547 & 1.829 \\
\hline IPLM & .196 & .025 & .382 & 7.823 & .000 & .571 & 1.750 \\
\hline \multicolumn{7}{|c|}{ Dependent Variable: IOE } \\
\hline
\end{tabular}

The table 2 shows that Work in Progress Management aspect of RFID Practices has positive relationship with Improved Efficiency; as the regression co-efficient is + 0.139 . The significance level of 0.012 indicates that this regression co-efficient is statistically very significant. So, null hypothesis $\mathrm{H}_{(\mathrm{WIPM}) 0}$ is rejected and alternate hypothesis $\mathrm{H}_{(\mathrm{WIPM}) 1}$ is accepted that there is a significant impact of usage of RFID in Work in Progress Management on Improved Efficiency. This means usage of RFID in Work in Progress Management exerts significant influence over 
Improved Efficiency. An increase in usage of RFID in Work in Progress Management will bring about a significant increase in RFID usage in Improved Efficiency by number of times the value of regression co-efficient.

It may also be seen that Inventory Management aspect of RFID Practices has positive relationship with Improved Efficiency; as the regression co-efficient is +0.211 . The significance level of 0.000 indicates that this regression co-efficient is statistically very significant. So, null hypothesis $\mathrm{H}_{(\mathrm{IM}) 0}$ is rejected and alternate hypothesis $\mathrm{H}_{(\mathrm{IM}) 1}$ is accepted that there is a significant impact of usage of RFID in Inventory Management on Improved Efficiency. This means usage of RFID in Inventory management exerts significant influence over Improved Efficiency. An increase in usage of RFID in Inventory Management will bring about a significant increase in RFID usage in Improved Efficiency by number of times the value of regression co-efficient.

Also, Logistics Management aspect of RFID Practices has positive relationship with Improved Efficiency; as the regression co-efficient is +0.208 . The significance level of 0.000 indicates that this regression co-efficient is statistically very significant. So, null hypothesis $\mathrm{H}_{(\mathrm{LM}) 0}$ is rejected and alternate hypothesis $\mathrm{H}_{(\mathrm{LM}) 1}$ is accepted that there is a significant impact of usage of RFID in Logistics Management on Improved Efficiency. This means usage of RFID in Logistics Management exerts significant influence over Improved Efficiency. An increase in usage of RFID in Logistics Management will bring about a significant increase in RFID usage in Improved Efficiency by number of times the value of regression co-efficient.

The Warehouse Management aspect of RFID Practices also has positive relationship with Improved Efficiency; as the regression co-efficient is +0.332 . The significance level of 0.000 indicates that this regression co-efficient is statistically very significant. So, null hypothesis $\mathrm{H}_{(\mathrm{WM}) 0}$ is rejected and alternate hypothesis $\mathrm{H}_{(\mathrm{Wm}) 1}$ is accepted that there is a significant impact of usage of RFID in Warehouse Management on Improved Efficiency. This means usage of RFID in Warehouse Management exerts significant influence over Improved Efficiency. An increase in usage of RFID in Warehouse Management will bring about a significant increase in RFID usage in Improved Efficiency by number of times the value of regression co-efficient.

It is found that In-Process Logistics Management aspect of RFID Practices too has positive relationship with Improved Efficiency; as the regression co-efficient is +0.382 . The significance level of 0.000 indicates that this regression co-efficient is statistically very significant. So, null hypothesis $\mathrm{H}_{(\mathrm{IPLM}) 0}$ is rejected and alternate hypothesis $\mathrm{H}_{(\mathrm{IPLM}) 1}$ is accepted that there is a significant impact of usage of RFID in In-Process Logistics Management on Improved Efficiency. This means usage of RFID in In-Process Logistics Management exerts significant influence over Improved Efficiency. An increase in usage of RFID in In-Process Logistics Management will bring about a significant increase in RFID usage in Improved Efficiency by number of times the value of regression co-efficient.

Table 3. Model Summary

\begin{tabular}{|c|c|c|c|c|c|c|c|c|}
\hline \multirow{2}{*}{$\mathrm{R}$} & \multirow{2}{*}{ R Square } & \multirow{2}{*}{$\begin{array}{l}\text { Adjusted R } \\
\text { Square }\end{array}$} & \multirow{2}{*}{$\begin{array}{l}\text { Std. Error } \\
\text { of the } \\
\text { Estimate }\end{array}$} & \multicolumn{5}{|c|}{ Change Statistics } \\
\hline & & & & $\begin{array}{l}\text { R Square } \\
\text { Change }\end{array}$ & $\begin{array}{l}\text { R Square } \\
\text { Change }\end{array}$ & $\begin{array}{l}\text { R Square } \\
\text { Change }\end{array}$ & $\begin{array}{l}\text { R Square } \\
\text { Change }\end{array}$ & $\begin{array}{l}\text { R Square } \\
\text { Change }\end{array}$ \\
\hline $.968^{\mathrm{a}}$ & .937 & .931 & .08942 & .937 & .937 & .937 & .937 & .937 \\
\hline
\end{tabular}

Table 4. Variance Analysis of RFID Practices on Improved Efficiency

\begin{tabular}{|c|c|c|c|c|c|}
\hline Model & Sum of Squares & Df & Mean Square & F & Sig. \\
\hline Regression & 5.504 & 5 & 1.101 & 137.659 & $.000^{\mathrm{a}}$ \\
\hline Residual & .368 & 46 & .008 & & \\
\hline Total & 5.872 & 51 & & & \\
\hline
\end{tabular}

The variance analysis given in table 4 above shows $F=137.659$ at a significance level of 0.000 with $\mathrm{df}(5,46)$, which indicates that all regression co-efficient will be non zero.

The emerging Multiple Regression Equation is as under:

$$
\mathrm{IOE}=-0.157+0.139(\mathrm{WIP})+0.211(\mathrm{IM})+0.208(\mathrm{LM})+0.332(\mathrm{WM})+0.382(\mathrm{IPLM})
$$

As seen in table 3 , the adjusted $\mathrm{R}^{2}$, i.e. the co-efficient of determination stands at 0.931 indicating that the equation can explain 93.1\% variations in Improved Efficiency through RFID practices (WIPM, IM, LM, WM, IPLM). 


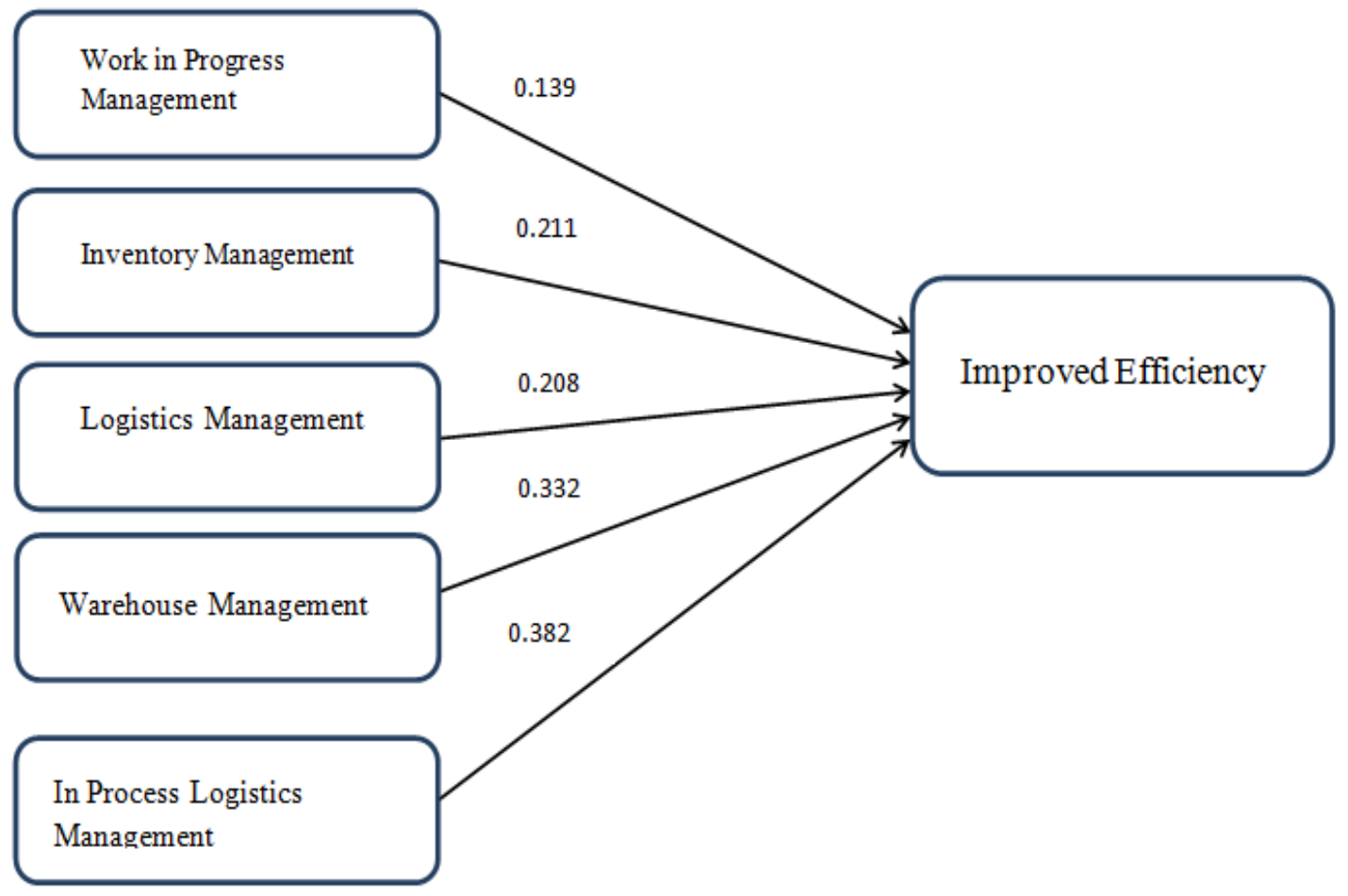

Figure 1. Relationship between RFID Practices and Improved Efficiency

Table 5. Correlation Coefficient

\begin{tabular}{|c|c|c|c|c|c|c|}
\hline & & WIPM & IM & LM & WM & IPLM \\
\hline \multirow{4}{*}{$\begin{array}{c}\text { Pearson } \\
\text { Correlation }\end{array}$} & WIPM & 1.000 & .566 & .590 & .529 & .505 \\
\cline { 2 - 7 } & IM & .566 & 1.000 & .388 & .579 & .406 \\
\cline { 2 - 7 } & WM & .590 & .388 & 1.000 & .478 & .592 \\
\cline { 2 - 7 } & IPLM & .505 & .579 & .478 & 1.000 & .253 \\
\cline { 2 - 7 } & & .592 & .253 & 1.000 \\
\hline
\end{tabular}

The co-efficient of correlation amongst all variables are depicted in the table 5 above. It is revealed that none of the five independent variables (Work in Progress Management, Inventory Management, Logistics Management, Warehouse Management and In-Process Logistics Management) has the co-efficient of correlation coefficient larger than +0.7 . The VIF statistics, in table 2, of all the independent variables are very much far from cut off rate of 10 . Hence, there is no cause of concern from viewpoint of multicollinearity among the independent variables.

As seen in the above figure 1, all the five practices namely, Work in Progress Management, Inventory Management, Logistics Management, Warehouse Management and In Process Logistics Management create an impact on the benefit of Improved Efficiency.

\section{Limitation of the Study}

The study includes survey of 52 manufacturing organizations using RFID technology. The sample size is therefore rather small. The study includes only 8 organizations which are fully conversant with all aspects of RFID technology. Moreover, the units surveyed were from Gujarat State of India, hence results need precaution for generalization.

\section{Conclusions}

RFID is proved to be an important innovation that leads to improve the operations of manufacturing companies. RFID technology though being costly, can improve the efficiency of organizations, and hence can be cost effective in the longer run. RFID technology has various applications in the manufacturing organizations, like inventory management, warehouse management, work in progress management, logistics management and in process logistics management. It is found that the application of RFID technology in anyone of these will improve the efficiency of the organization. Thus, the finding of the study is that inspite of the cost involved, which organizations consider as higher, the benefits in the long run will out way the cost.

\section{REFERENCES}

[1] Hunt, V. D., Puglia, A. and Puglia, M. (2006),"RFID Regulations and Standards, in RFID-A Guide to Radio Frequency Identification”, John Wiley \& Sons, Inc., Hoboken, NJ, USA. doi: 10.1002/9780470112250.ch7 
[2] Makhija, Diljeetkaur G., and Chugan, Pawan. K. (2016), "RFID Based Library Management System: The Benefits and Challenges", published in New Age Ecosystem for Empowering Trade, Industry and Society, Institute of Management, Nirma University. NICOM 2016, pp.: 210-231.

[3] Hamilton, D., Michael. K., \& Fosco., S. (2010), Overcoming Visibility issues in a small-to-Medium retailer Using Automatic Identification and Data Capture technology: an evolutionary approach. International Journal of E-Business Research, 6(2), 21-44, April-June 2010.

[4] Finkenzeller, K. (2003). Introduction. RFID Handbook: Fundamentals and Applications in Contactless Smart Cards and Identification, Second Edition, 1-9

[5] Garfinkel, S., \& Rosenberg, B. (2005), "RFID: Applications, Security, and Privacy", Upper Saddle River, NJ: Addison-Wesley.

[6] Kulkarni, G., Rambade S., Kamble S., Doke A., Khan R.A. (2014), "Cloud Based Supply Chain Management", International Journal of Scientific \& Engineering Research, Volume 5, Issue 4, April, 361-365.

[7] Cachon, G. and Fisher, M. (2000), "Supply chain inventory management and the value of shared information", Management Science, Vol. 46, No. 8, pp.1032-1048.

[8] Mills-Harris, M.D., Soylemezoglu, A., and Saygin, C., (2005), "RFID data-based inventory management of time-sensitive materials", In: Proceedings of the 31st annual conference of the IEEE Industrial Electronics Society (IECON'05).

[9] Strassner, B. and Chang, K., (2003), "Passive 5.8-GHz radio-frequency identification tag for monitoring oil drill pipe", IEEE Transactions on Microwave Theory and Techniques, 51 (2), 356-363.

[10] Lampe, M., Strassner, M., and Fleisch, E., (2006), "RFID in movable asset management, In: G. Roussos, ed. Ubiquitous and pervasive commerce", New York: Springer, 53-74.

[11] Huang, G.Q., Zhang, Y.F., and Jiang, P.Y., (2007), "RFID-based wireless manufacturing for real-time management of job shop WIP inventories", International Journal of Advanced Manufacturing Technology, 36 (7), $752-764$.

[12] Brewer, A., Sloan, N. and Landers, T.L. (1999), "Intelligent tracking in manufacturing", Journal of Intelligent Manufacturing, Vol. 10 Nos 3/4, pp. 245-50.

[13] Li, S., Visich, J.K., Khumawala, B.M., and Zhang, C., (2006), "Radio frequency identification technology: applications. Technical Challenges and Strategies", Sensor Review, 26, 193-202.

[14] Makhija, Diljeetkaur G., and Chugan, Pawan. K. (2015), "Identifying the Drivers for Adoption of RFID Technology: A Study of Manufacturing Organizations", International Journal of Information Technology and Computer Sciences Perspectives. Pezzottaite Journals. Voulme 4, Number 3, pp.; 1635-1642. http://papers.ssrn.com/abstract $=2684735$

[15] Heikkila", J. (2002), "From supply to demand chain management: efficiency and customer satisfaction", Journal of Operations Management, Vol. 20 No. 6, pp. 747-67.

[16] Green, K.W. Jr, Whitten, D. and Inman, R.A. (2009), “The impact of RFID technology utilization on supply chain productivity and organizational performance", International Journal of Innovation and Learning, Vol. 6 No. 2, pp. 147-62.

[17] Stambaugh, C. T. and Carpenter, F.W. (2009), "RFID", Strategic Finance, Vol. 91 No. 6, pp. 35-40.

[18] Zhou, W. (2009), "RFID and item-level information visibility", European Journal of Operational Research, Vol. 198 No. 1, pp. 252-8.

[19] Zelbst, P.J., Green, K. W. Jr, Baker, G. and Sower, V.E. (2010), "RFID utilization and information sharing impact supply chain performance", Journal of Business \& Industrial Marketing, Vol. 25 No. 8, pp. 582-9.

[20] Angeles, R. (2007), "An empirical study of the anticipated consumer response to RFID product item tagging", Industrial Management \& Data Systems, Vol. 107 No. 4, pp. 461-83.

[21] Michael, M. and McCathie, L. (2005), "The pros and cons of RFID in supply chain management", Proceedings of the International Conference on Mobile Business, 11-13 July, pp. 623-9.

[22] Günther, O. P., Kletti, W., \&Kubach, U. (2008), "RFID in Manufacturing. Springer Science \& Business Media".

[23] Bendavid, Y., Wamba, S. F., \& Lefebvre, L. A. (2006), "Proof of concept of an RFID-enabled supply chain in a B2B e-commerce environment", In Proceedings of the 8th international conference on Electronic commerce: The new e-commerce: innovations for conquering current barriers, obstacles and limitations to conducting successful business on the internet (pp. 564 - 568 ). NY, USA ACM

[24] Chan, F.T.S. and Chan, H.K. (2005), "The future trend on system-wide modelling in supply chain studies", International Journal of Advanced Manufacturing Technology, Vol. 25 Nos 7-8, pp. 820-32.

[25] Cheung, Y. Y., Choy, K. L., Lau, C. W., \& Leung, Y. K. (2008), "The Impact of RFID Technology on the Formulation of Logistics Strategy", In Proceedings of the Portland International Conference on Management of Engineering \& Technology (pp. 1673 - 1680 ): IEEE Computer Society.

[26] Chorafas, D. (2001), "Strategic management of spare parts in closed-loop supply chain - a system dynamics approach", Interfaces, Vol. 33 No. 6, pp. 7-17.

[27] Hair, J.H. Jr., Balck, W.C., Babin, B.J., Anderson, R.E. and Tatham, R.L. (2009). Multivariate Data Analysis. Sixth Edition, Pearson Education

[28] Malhotra, N.K. and Dash, S. (2010), "Marketing Research An Applied Orientation', Sixth Edition, Pearson Education, New Delhi.

[29] Keith, T.Z. (2006), "Multiple Regression and Beyond”,Allyn and Bacon, Boston, Pearson Education.

[30] Kutner, M.H., Nachtsheim, C.J. and Neter, J. (2005), “Applied Linear Statistical Models", Fifth Edition, McGraw-Hill, Singapore 